\title{
Pengaruh Rhizobacteria pada Pertumbuhan dan Hasil Tanaman Bawang Merah (Allium ascalonicum L.) pada Kondisi Salin
}

\author{
Effect of Rhizobacteria on Growth and Yield of Shallots (Allium ascalonicum L.) \\ in Saline Conditions \\ Nurul Aini ${ }^{1 *}$, Wiwin Sumiya Dwi Yamika ${ }^{1}$, Luqman Qurata Aini ${ }^{2}$, Nur Azizah ${ }^{1}$ \\ dan Elok Sukmarani ${ }^{3}$
}

Diterima 28 Mei 2019/Disetujui 04 November 2019

\begin{abstract}
The aim of this study was to determine the effect of bacteria on the growth and yield of shallots (Allium ascalonicum L.) under salin condition. The research was conducted at Agrotechnopark Greenhouse of Brawijaya University from February to June 2018. The bacterial isolates were used are SN13 (Streptomyces sp.), SN22 (Bacillus sp.) and SN23 (Corynebacterium sp.) isolated from the soil of saline area of Lamongan, East Java Indonesia. The experiment used a split plot designs, consist of saline condition treatment as a main plot and various consentrations of bacteria treatment as sub plot. The results showed that bacteria inoculated plants had very significant root dry weight (22.10-30\%), chlorophyll amount (reach up 26.03\%) compared to controls (without bacterial inoculation), but reduced allicin content in the tuber of shallot. Bacteria did not affect the number of leaves, the proline content and the yield components of shallots under saline conditions. The application of endemic saline bacteria can improve plant growth under saline conditions. Saline conditions reduce both growth and yield of shallots, but increase the content of proline. The increasing proline concentration in leaves was the physiological response of shallot grown in saline conditions
\end{abstract}

Keywords: allicin, bulb, chlorophyll, proline, salinity

\begin{abstract}
ABSTRAK
Tujuan penelitian ini untuk menentukan pengaruh rhizobakteri pada pertumbuhan, klorofil dan kandungan allisin tanaman bawang merah (Allium ascalonicum L.) dalam kondisi salin. Penelitian ini dilakukan di Rumah Kaca di Agrotechnopark Universitas Brawijaya yang dilaksanakan mulai bulan Februari sampai Juni 2018. Strain rhizobakteri yang digunakan terdiri dari isolat-isolat bakteri toleran salin berasal dari tanah salin di pesisir Lamongan, Jawa Timur, Indonesia dengan kode isolat SN13 (Streptomyces sp.), SN22 (Bacillus sp.) and SN23 (Corynebacterium sp.). Rancangan percobaan yang digunakan dalam penelitian ini adalah rancangan petak terbagi (split plot), terdiri dari kondisi salin sebagai petak utama dan konsentrasi bakteri toleran salin sebagai anak petak. Hasil penelitian menunjukkan bahwa tanaman yang diinokulasi bakteri mempunyai bobot kering akar yang sangat nyata lebih tinggi (22.10-30\%), jumlah klorofil (mencapai 26.03\%) lebih tinggi dibandingkan tanpa inokulasi, tetapi memiliki allisin pada umbinya lebih rendah. Aplikasi bakteri toleran salin dapat memperbaiki pertumbuhan tanaman dalam kondisi salin. Kondisi salin menurunkan baik pertumbuhan dan hasil tanaman bawang merah, namun meningkatkan kandungan prolin. Peningkatan konsentrasi prolin pada daun merupakan respon fisiologis dari tanaman bawang merah pada kondisi salin.
\end{abstract}

Kata kunci: allisin, klorofil, prolin, salinitas, umbi

${ }^{1}$ Departmen Budidaya Pertanian, Fakultas Pertanian, Universitas Brawijaya

Jl. Veteran, Malang 65145, Jawa Timur.

${ }^{2}$ Departmen Hama dan Penyakit Tumbuhan, Fakultas Pertanian, Universitas Brawijaya

Jl. Veteran, Malang 65145, Jawa Timur.

${ }^{3}$ Program Sarjana Agroekoteknologi, Departemen Budidaya Pertanian, Fakultas Pertanian, Universitas Brawijaya

Jl. Veteran, Malang 65145, Jawa Timur.

E-mail: nurulrulyaini@gmail.com (*Penulis korespondensi) 


\section{PENDAHULUAN}

Bawang merah (Allium ascalonicum L.) mempunyai prospek pasar yang baik sehingga termasuk dalam komoditas unggulan nasional (Rahmi et al., 2016). Peningkatan produksi bawang merah menjadi peluang dan dapat menjadi motivasi bagi petani, oleh karena itu, diperlukan upaya peningkatan produksi bawang merah, diantaranya dengan perbaikan teknik budidaya dan perluasan areal penanaman. Salah satu upaya untuk meningkatkan produksi bawang merah adalah dengan memanfaatkan lahan marginal, seperti tanah salin. Namun, salinitas tanah berpengaruh buruk terhadap pertumbuhan tanaman dan menurunkan hasil. Kendala utama dalam kondisi cekaman salinitas adalah tingginya kandungan garam, terutama $\mathrm{NaCl}$. Peningkatan konsentrasi garam dalam tanah memengaruhi turgor, fotosintesis, dan atau aktivitas enzim spesifik (Motos et al., 2017), menurunkan hormon pertumbuhan auksin, sitokinin dan meningkatkan hormon etilen serta asam absisat. Hal ini menyebabkan tanaman menutup stomata dan cepat mengalami senesence. Namun demikian tanaman mempunyai mekanisme untuk dapat bertahan pada kondisi cekaman salin diantaranya dengan mengakumulasi berbagai molekul seperti prolin, glukosa dan glisin betain. Senyawa-senyawa ini yang berfungsi sebagai osmoregulator yang dapat melindungi sel dan aktivitas enzim (Jha dan Subramanian, 2013).

Beberapa upaya telah dilakukan untuk mengatasi salinitas berpengaruh buruk terhadap tanaman, termasuk upaya kimia dan biologis. Salah satu upaya untuk mengatasi masalah salinitas tanah adalah melalui pemanfaatan mikroorganisme tanah seperti bakteri yang dapat hidup pada kondisi lingkungan salin. Beberapa jenis bakteri tersebut dapat menghasilkan berbagai hormon pertumbuhan serta memfasilitasi tanaman dalam menyerap unsur hara sehingga dapat dikelompok dalam Plant Growth Promoting Rhizobacteria (PGPR) yang dapat meningkatkan pertumbuhan tanaman melalui perannya sebagai biostimulan maupun biofertilizer. Koloni hidup mikroba PGPR dalam akar tanaman bermanfaat untuk meningkatkan kesehatan tanaman dan mendorong pertumbuhan tanaman. Mikroorganisme di sekitar akar tanaman yang hidup dalam kondisi kurang optimal seperti salin, mampu meningkatkan toleransi tanaman terhadap cekaman salin. Berdasarkan penelitian dari Cahyaty et al. (2017), aplikasi bakteri endemik salin dengan konsentrasi $30 \mathrm{ml} \mathrm{L}^{-1}$ terbukti dapat meningkatkan produksi mentimun dalam kondisi salin hingga 26\% dibanding kontrol tanpa PGPR. Dijelaskan lebih lanjut bahwa hal ini dikarenakan bakteri endemik salin telah diuji mampu memproduksi hormon Indole Acetik Acid (IAA). Tujuan penelitian ini adalah mempelajari aplikasi bakteri toleran salin yang berasal dari pengaruh eksplorasi di Kabupaten Lamongan terhadap pertumbuhan, hasil, kandungan prolin dan allicin bawang merah dalam kondisi salin.

\section{BAHAN DAN METODE}

Penelitian dilakukan di Rumah Kaca di Agrotechnopark Universitas Brawijaya, Desa Jatikerto, Malang, Jawa Timur. Penelitian dilaksanakan mulai bulan Februari sampai Juni 2018. Bibit bawang merah yang digunakan untuk penelitian adalah varietas Bauji. Polibag diisi dengan media tanam yang terdiri dari campuran pasir, arang sekam, dan cocopeat dengan perbandingan 4:1:1. Komposisi nutrisi terdiri dari: $5 \mathrm{Ca}\left(\mathrm{NO}_{3}\right) 2 ; \quad \mathrm{NH}_{4} \mathrm{NO}_{3} \cdot 10 \mathrm{H}_{2} \mathrm{O}$; $\mathrm{KNO}_{3} ; \quad \mathrm{C}_{10} \mathrm{H}_{13} \mathrm{FeN}_{2} \mathrm{O}_{8} ; \quad \mathrm{KH}_{2} \mathrm{PO}_{4} ; \quad \mathrm{K}_{2} \mathrm{SO}_{4}$; $\mathrm{MgSO}_{4} .7 \mathrm{H}_{2} \mathrm{O} ; \quad\left(\mathrm{NH}_{4}\right) 2 \mathrm{SO}_{4} ; \mathrm{ZnSO}_{4} ; \mathrm{H}_{3} \mathrm{BO}_{3}$, $\mathrm{MnSO}_{4} \cdot 4 \mathrm{H}_{2} \mathrm{O} ; \mathrm{CuSO}_{4}$ dan $\mathrm{Na}_{2} \mathrm{MoO}_{4}$. Bakteri yang digunakan adalah isolat dengan kode SN13 (Streptomyces sp.), SN22 (Bacillus sp.) dan SN23 (Corynebacterium sp.). Isolat bakteri diisolasi dari rizosfer tumbuhan (akar dan tanah di sekitar perakaran) yang hidup di lahan salin di daerah pesisir utara Kecamatan Brondong Kabupaten Lamongan, Jawa Timur.Isolat bakteri selanjutnya diperbanyak dan dilakukan pengujian (uji hipersensitifitas pada daun tembakau, uji produksi IAA dan penambatan N) di Laboratorium Bakteriologi Jurusan Hama dan Penyakit Tumbuhan Fakultas Pertanian Universitas Brawijaya Malang. Isolat bakteri dibiakkan pada media Nutrient Agar (NA) dan diinkubasi selama 24 jam kemudian hasil bakteri yang tumbuh ditumbuhkan pada media cair Nutrient Broth (NB) dan dilakukan shaking selama 2 x 24 jam dengan kecepatan $150 \mathrm{rpm}$. Setelah didapatkan nilai Optical Density (OD) $\geq 1$, selanjutnya suspesi bakteri diencerkan hingga memiliki kerapatan $1 \times 10^{9} \mathrm{cfu} \mathrm{ml}^{-1}$. Isolat bakteri yang 
digunakan sudah dilakukan pengujian dan terbukti berpotensi untuk menghasilkan hormon IAA dan menambat $\mathrm{N}$ (Cahyaty et al., 2017).

Rancangan percobaan yang digunakan adalah rancangan petak terbagi yang terdiri dari dua faktor dengan tiga ulangan. Petak utama adalah kondisi salin $(\mathrm{P})$, terdiri dari $\mathrm{P} 0=$ non salin (nilai EC $2-3 \mu \mathrm{S} \mathrm{cm}^{-1}$ ) dan $\mathrm{P} 1=$ salin (nilai EC $4-5 \mu \mathrm{S} \mathrm{cm}^{-1}$ ) (Yadav et al., 2011), sedangkan anak petak adalah konsentrasi bakteri endemik salin $(\mathrm{K})$, terdiri dari $\mathrm{K} 0=$ tanpa isolat; $\mathrm{K} 1=$ konsentrasi $7.5 \mathrm{ml} \mathrm{L}^{-1} ; \mathrm{K} 2=$ konsentrasi $15 \mathrm{ml}$ $\mathrm{L}^{-1} ; \mathrm{K} 3=$ konsentrasi $22.5 \mathrm{ml} \mathrm{L}^{-1}$ dan $\mathrm{K} 4=$ konsentrasi $30 \mathrm{ml} \mathrm{L}^{-1}$. Percobaan menggunakan sistem hidroponik substrat dan irigasi menggunakan teknik irigasi tetes.Disain irigasi didasarkan pada kebutuhan air tanaman dengan menggunakan perangkat lunak FAOCROPWAT 8.0. Perhitungan tersebut didasarkan pada data klimatologi Stasiun Karangkates Tahun 2016 (Badan Pusat Statistika Kabupaten Malang, 2017), koefisien tanaman (Kc), evapotranspirasi aktual (ETo) dan persamaan perhitungan ETo menggunakan metode Penmann-Montein (Allen et al., 1998). Hasil perhitungan yang didapatkan dari software FAOCROPWAT 8.0 menunjukkan kebutuhan air tanaman per hari serta durasi irigasi tetesnya (Tabel 1).

Pengisian air pada tandon dilakukan setiap 2 hari, dengan kontrol EC dan nilai $\mathrm{pH}$. Pada media tanam, kontrol nilai EC dilakukan seminggu sekali menggunakan metode Pour Thru.Simulasi kondisi salin menggunakan garam grasak yang ditambahkan pada tandon nutrisi tanaman sesuai perlakuan. Selama fase pertumbuhan vegetatif bawang merah, larutan nilai EC dari setiap perlakuan diberikan hingga $1.8 \mu \mathrm{S} \mathrm{cm}{ }^{-1}$ untuk perlakuan non-salin, tetapi perlakuan kondisi salin tambahan $200 \mathrm{~g}$ garam grasak hingga $3 \mu \mathrm{S} \mathrm{cm}^{-1}$. Selama fase pembentukan umbi bawang merah, nilai EC dalam larutan dinaikkan hingga $4 \mu \mathrm{S} \mathrm{cm}$ dengan menambahkan $400 \mathrm{~g}$ garam grasak. Bakteri endemik salin diaplikasikan 1, 2, 3 dan 4 minggu setelah tanam (MST) dengan menuangkan $20 \mathrm{ml}$ suspensi bakteri dengan kerapatan $1 \times 10^{9} \mathrm{ml} \mathrm{L}^{-1}$ pada area perakaran masing-masing tanaman (Gul et al., 2008).

Pengamatan meliputi pertumbuhan tanaman, komponen hasil dan hasil.Selain itu juga dilakukan pengamatan fisiologis yang meliputi kandunga prolin daun dan allisin.

\section{Pertumbuhan Tanaman}

Data peubah pertumbuhan tanaman meliputi luas daun, jumlah daun dan berat kering akar, dan berat kering brangkasan tanaman. Pengukuran luas daun dilakukan dengan menggunakan metode silindris untuk jenis dan bentuk daun berlubang atau silindris. Bobot kering akar dan brangkasan tanaman ditimbang setelah dikeringkan dalam oven dengan suhu $80{ }^{0} \mathrm{C}$ sampai berat kering konstan.

\section{Komponen Hasil}

Data komponen hasil meliputi diameter umbi, jumlah umbi dan berat kering umbi per rumpun. Panen bawang merah dilakukan saat tanaman berumur 82 hari setelah tanam dengan indikator daun menguning atau kering mencapai $90 \%$. Setelah panen, umbi bawang merah dikeringkan di bawah sinar matahari selama 14 hari dan kemudian diukur berat keringnya.

Tabel 1. Hasil perhitungan kebutuhan air tanaman dan durasi irigasi tetes

\begin{tabular}{|c|c|c|c|c|c|c|c|}
\hline \multirow[t]{2}{*}{ Bulan } & \multirow[t]{2}{*}{ Tanggal } & \multirow[t]{2}{*}{ Fase } & \multirow{2}{*}{$\begin{array}{c}\text { Kc } \\
\text { Tanaman }\end{array}$} & Eto & Kebutuhan Air & $\begin{array}{c}\text { Frekuensi } \\
\text { Aplikasi }\end{array}$ & $\begin{array}{l}\text { Durasi } \\
\text { Irigasi }\end{array}$ \\
\hline & & & & $\mathrm{mm} / \mathrm{hari}$ & ml/tanaman & aplikasi/hari & min/aplikasi \\
\hline Maret & $21-31$ & Initial & 1.00 & 4.51 & 451 & 8 & 1 \\
\hline April & $1-10$ & Initial & 1.00 & 4.44 & 444 & 7 & 1 \\
\hline April & $11-20$ & Development & 1.00 & 4.36 & 436 & 7 & 1 \\
\hline Mei & $21-31$ & Mid-season & 0.98 & 3.89 & 389 & 7 & 1 \\
\hline Juni & $1-6$ & Late season & 0.69 & 2.67 & 267 & 5 & 1 \\
\hline
\end{tabular}




\section{Analisis Kandungan Klorofil, Prolin dan Allisin}

Jumlah klorofil dianalisis berdasarkan metode Porra. Analisis menggunakan spektrofotometer berdasarkan nilai absorbansi $\lambda 663$ dan $\lambda 646$ yang dilakukan saat tanaman berumur 8 minggu setelah tanam. Sedangkan, pengukuran kandungan prolin dilakukan saat tanaman berumur 8 minggu setelah tanam. Kandungan prolin pada daun tanaman dianalisis menggunakan metode Bates. Kadar allisin umbi diukur berdasarkan metode HPLC yang dilakukan setelah pemanenan umbi.

\section{Analisis Statistik}

Data yang diperoleh dianalisis dengan analisis varian dua arah (ANOVA) dengan tingkat signifikan $p=0.05$. Setelah itu, data dianalisis lebih lanjut menggunakan uji Beda Nyata Jujur (BNJ) Tukey pada tingkat 5\% $(\alpha=$ 0.05), untuk mengetahui peubah yang menunjukkan respon nyata.

\section{HASIL DAN PEMBAHASAN}

Secara umum hasil penelitian menunjukkan bahwa tidak terjadi interaksi antara kondisi salin dan konsentrasi bakteri salin yang diaplikasikan, kecuali tiada kandungan allisin. Kondisi salin menurunkan peubah pertumbuhan seperti jumlah daun, namun tidak berpengaruh terhadap luas daun, bobot kering akar, dan kandungan total klorofil. Salinitas nyata menurunkan peubah hasil seperti jumlah umbi, diameter umbi dan bobot kering umbi per rumpun, sedangkan aplikasi bakteri endemik salin, meningkatkan beberapa peubah pertumbuhan seperti bobot kering akar, dan total klorofil. Namun, bakteri toleran salin belum menunjukkan berpengaruh nyata terhadap jumlah umbi, diameter umbi dan bobot kering umbi per tanaman.

\section{Pengaruh Bakteri Endemik Salin dan Kondisi Salin terhadap Pertumbuhan Vegetatif dan Kandungan Klorofil}

Jumlah daun umur 8 MST dipengaruhi secara nyata oleh kondisi salin. Daun tanaman bawang merah yang tumbuh pada media salin lebih sedikit dibanding non-salin. Sebaliknya luas daun tidak dipengaruhi oleh kondisi salin. Salinitas dapat menyebabkan penurunan potensial air pada media sehingga tanaman sulit menyerap air dan unsur hara dari media tanam. Air dan unsur hara sangat diperlukan dalam proses pertumbuhan seperti penambahan daun. Konsentrasi bakteri toleran salin menurunkan jumlah daun tanaman bawang merah.

Penurunan jumlah daun ini merupakan salah satu respon tanaman saat kondisi tercekam yang diduga sebagai respon tanaman dalam proses transpirasi tanaman. Apabila semakin sedikit jumlah daun yang dihasilkan, maka proses transpirasi berkurang sehingga mempengaruhi proses fotosintesis dan hasil fotosintatnya. Hal ini sejalan dengan hasil penelitian Kusumiyati et al. (2017) bahwa dengan adanya keberadaan garam tinggi, tanaman asparagus pada tahap vegetatif merespon dengan mengurangi jumlah daun agar tidak terlalu besar kehilangan air saat proses transpirasi.

Tabel 2. Pengaruh kondisi salin dan konsentrasi bakteri pertumbuhan tanaman bawang merah pada umur 8 MST.

\begin{tabular}{|c|c|c|c|c|}
\hline Perlakuan & Jumlah Daun* & $\begin{array}{l}\text { Luas Daun } \\
\left(\mathrm{cm}^{2} \tan ^{-1}\right)\end{array}$ & $\begin{array}{c}\text { Bobot Kering } \\
\begin{array}{c}\text { Akar } \\
\left(\mathrm{g} \mathrm{tan}^{-1}\right)^{*}\end{array} \\
\end{array}$ & $\begin{array}{c}\text { Bobot Kering } \\
\text { Brangkasan } \\
\left(\mathrm{g} \mathrm{tan}^{-1}\right)\end{array}$ \\
\hline Non salin $\left(\mathrm{P}_{0}\right)$ & $64.2 \mathrm{~b}$ & 384.5 & 1.5 & 3.56 \\
\hline$\underline{\operatorname{Salin}}\left(\mathrm{P}_{1}\right)$ & $47.9 \mathrm{a}$ & 221.3 & 1.3 & 2.90 \\
\hline BNJ 5\% & 4.25 & tn & tn & tn \\
\hline Konsentrasi $0 \mathrm{ml} \mathrm{L}^{-1}\left(\mathrm{~K}_{0}\right)$ & 57.2 & 286.6 & $7.4 \mathrm{a}$ & 17.3 \\
\hline Konsentrasi $7.5 \mathrm{ml} \mathrm{L}^{-1}\left(\mathrm{~K}_{1}\right)$ & 56.9 & 264.4 & $8.4 \mathrm{c}$ & 20.0 \\
\hline Konsentrasi $15 \mathrm{ml} \mathrm{L}^{-1}\left(\mathrm{~K}_{2}\right)$ & 56.1 & 280.5 & $8.2 \mathrm{bc}$ & 19.6 \\
\hline Konsentrasi $22.5 \mathrm{ml} \mathrm{L}^{-1}\left(\mathrm{~K}_{3}\right)$ & 54.3 & 336.8 & $8.1 \mathrm{~b}$ & 20.4 \\
\hline Konsentrasi $30 \mathrm{ml} \mathrm{L}^{-1}\left(\mathrm{~K}_{4}\right)$ & 55.8 & 346.3 & $9.5 \mathrm{~d}$ & 19.7 \\
\hline BNJ $5 \%$ & tn & tn & 0.21 & tn \\
\hline
\end{tabular}

Keterangan: $\mathrm{tn}=$ tidak berbeda nyata; *angka yang diikuti huruf yang sama pada kolom yang sama tidak berbeda nyata pada uji BNJ dengan $\alpha=0.05$, MST $=$ minggu setelah tanam. 
Konsentrasi bakteri yang diaplikasikan tidak berpengaruh terhadap jumlah daun. Aplikasi bakteri juga nyata meningkatkan bobot kering akar. Berdasarkan Tabel 2, konsentrasi bakteri $30 \mathrm{ml} \mathrm{L}^{-1}$ meningkatkan bobot kering akar hingga mencapai $22.10 \%$ pada 8 MST. Berbeda dengan bobot akar, bobot kering brangkasan (tajuk) tidak dipengaruhi oleh konsentrasi bakteri. Baik bobot kering akar maupun bobot kering brangkasan tidak dipengaruhi oleh salinitas (Tabel 2). Peningkatan bobot kering akar dengan aplikasi bakteri toleran salin kemungkinan karena peran bakteri yang mampu memproduksi hormon pertumbuhan IAA (Indole 2 Acited Acid). Hal ini terbukti dari hasil penelitian kami sebelumnya secara in vitro (data tidak dipublikasikan), bahwa bakteri endemik salin dengan kode isolat SN13 mampu menghasilkan hormon IAA sebesar 4.83 ppm, SN22 menghasilkan 10.08 ppm dan SN23 menghasilkan $2.10 \mathrm{ppm}$. Hormon IAA mampu menghambat peningkatan hormon etilen saat tanaman dalam kondisi tercekam. Hormon etilen yang menyebabkan pertumbuhan tanaman menjadi terhambat atau terganggu. Menurut Widawati (2015) bakteri yang mampu memproduksi hormon IAA dapat memacu pertumbuhan tanaman dan dapat hidup pada kondisi cekaman abiotik seperti kondisi salin. Mekanisme bakteri penghasil hormon IAA dimulai dari eksudat akar atau sel-sel yang rusak yang didalamnya mengandung asam amino L-triptofan, yaitu prekursor dalam biosinesis IAA pada tanaman dan mikroba, oleh karena itu, bakteri ataupun mikroorganisme yang terdapat di sekitar perakaran memanfaatkan eksudat akar sebagai sumber energi bagi bakteri (Taghavi et al., 2009). Radhakrishnan dan Baek (2017) menemukan beberapa bakteri toleran salin dan metabolisme mereka dapat mengurangi dampak buruk dari cekaman salinitas pada tanaman dengan mengatur kondisi fisiologis sel-sel tanaman tersebut. Namun pada penelitian ini, peningkatan bobot kering akar belum diikuti oleh peningkatan bobot kering brangkasan.

Konsentrasi bakteri toleran salin juga mempengaruhi peningkatan jumlah klorofil hingga mencapai $26.03 \%$ dengan konsentrasi $22.5 \mathrm{ml} \mathrm{L}^{-1}$ dibandingkan dengan jumlah klorofil perlakuan kontrol tanpa aplikasi bakteri (Tabel 3). Tanaman yang diinokulasi isolat bakteri menunjukkan jumlah klorofil yang lebih banyak dibandingkan tanaman tanpa isolat bakteri. Sejalan dengan penelitian yang dilakukan oleh Nadeem et al. (2006), terjadi penurunan jumlah klorofil pada tanaman jagung yang mengalami cekamansalinitas, tetapi dengan adanya inokulasi bakteri terjadi peningkatan pigmen klorofil. Peran bakteri pada penelitian ini tentunya dapat dikaitkan dengan peningkatan pigmen klorofil tersebut karena bakteri SN13, SN22 dan SN23 berdasar pada penelitian kami sebelumnya terbukti mampu menambat nitrogen (Cahyati et al., 2017), karena nitrogen inilah yang berfungsi sebagai komponen penyusun klorofil. Menurut Ohyama (2010), peningkatan kandungan nitrogen tanaman mempengaruhi tingkat fotosintesis melalui peningkatan klorofil. Hasil penelitian menunjukkan bahwa klorofil tidak dipengaruhi oleh salinitas.

Tabel 3. Pengaruh konsentrasi bakteri dan salinitas pada kandungan klorofil

\begin{tabular}{|c|c|}
\hline Perlakuan Konsentrasi Bakteri & Total Klorofil $\left(\mathrm{mg} \mathrm{g}^{-1}\right)^{*}$ \\
\hline $0 \mathrm{ml} \mathrm{L}^{-1}\left(\mathrm{~K}_{0}\right)$ & $8.484 \mathrm{a}$ \\
\hline $7.5 \mathrm{ml} \mathrm{L}^{-1}\left(\mathrm{~K}_{1}\right)$ & $11.471 \mathrm{~b}$ \\
\hline $15 \mathrm{ml} \mathrm{L}^{-1}\left(\mathrm{~K}_{2}\right)$ & $11.742 \mathrm{~b}$ \\
\hline $22.5 \mathrm{ml} \mathrm{L}^{-1}\left(\mathrm{~K}_{3}\right)$ & $11.846 \mathrm{~b}$ \\
\hline $30 \mathrm{ml} \mathrm{L}^{-1}\left(\mathrm{~K}_{4}\right)$ & $11.809 \mathrm{~b}$ \\
\hline
\end{tabular}

Keterangan: *angka yang diikuti huruf yang sama tidak berbeda nyata pada uji BNJ dengan $\alpha=0.05$, MST $=$ minggu setelah tanam. 


\section{Pengaruh Bakteri Endemik Salin dan Kondisi Salin pada Komponen Hasil Bawang Merah}

Berdasarkan Tabel 4, rerata jumlah umbi, diameter umbi dan bobot kering umbi tanaman bawang merah dipengaruhi oleh salinitas. Salinitas, menyebabkan penurunan diameter umbi bawang merah sebesar $14.28 \%$ dibandingkan pada kondisi non-salin. Pengamatan pada bobot segar dan bobot kering umbi per tanaman dalam kondisi salin juga menunjukkan penurunan hingga mencapai $26.12 \%$ dan $34.44 \%$ dibandingkan pada kondisi non salin. Salinitas dapat menyebabkan penurunan potensial air pada media sehingga tanaman sulit menyerap air dan unsur hara dari media tanam. Air dan unsur hara sangat diperlukan dalam proses pembentukan dan pembesaran umbi.

Pada penelitian ini meskipun konsentrasi bakteri salin berpengaruh terhadap peubah bobot kering akar dan kandungan klorofil daun, namun belum mampu meningkatkan bobot umbi bawang merah. Hal ini kemungkinan karena penelitian ini dilakukan menggunakan sistem hidroponik dimana nutrisi tanaman terpenuhi sesuai kebutuhan tanaman bawang merah.Pada penelitian ini meskipun bobot kering umbi menurun dengan kondisi salin, namun hasil umbi masih relatif tinggi sesuai dengan potensi dari varietas Bauji.

\section{Kandungan Prolin dan Allisin}

Kandungan prolin tidak dipengaruhi oleh perlakuan bakteri endemik salin dengan berbagai konsentrasi, tetapi berbeda nyata akibat perlakuan kondisi salin (Gambar 1). Kandungan prolin meningkat pada tanaman bawang merah umur 8 MST yang mengalami cekaman salin.

Tabel 4. Pengaruh bakteri endemik salin dan salinitas pada jumlah umbi per rumpun, diameter umbi dan bobot kering umbi per rumpun

\begin{tabular}{|c|c|c|c|}
\hline Perlakuan & $\begin{array}{l}\text { Jumlah Umbi per } \\
\text { Rumpun* }\end{array}$ & $\begin{array}{l}\text { Diameter Umbi } \\
\qquad(\mathrm{mm})^{*}\end{array}$ & $\begin{array}{c}\text { Bobot Kering } \\
\text { Umbi } \\
\left.\text { (g rumpun }^{-1}\right)^{*}\end{array}$ \\
\hline Non salin $\left(\mathrm{P}_{0}\right)$ & $18.7 \mathrm{~b}$ & $26.6 \mathrm{~b}$ & $131.8 \mathrm{~b}$ \\
\hline Salin $\left(\mathrm{P}_{1}\right)$ & $14.6 \mathrm{a}$ & $22.8 \mathrm{a}$ & $86.4 \mathrm{a}$ \\
\hline BNJ 5\% & 1.6 & 2.9 & 11.8 \\
\hline Konsentrasi $0 \mathrm{ml} \mathrm{l}^{-1}\left(\mathrm{~K}_{0}\right)$ & 16.4 & 24.5 & 107.3 \\
\hline Konsentrasi $7.5 \mathrm{ml} \mathrm{l}^{-1}\left(\mathrm{~K}_{1}\right)$ & 16.2 & 24.9 & 100.3 \\
\hline Konsentrasi $15 \mathrm{ml} \mathrm{l}^{-1}\left(\mathrm{~K}_{2}\right)$ & 16.9 & 23.9 & 106.4 \\
\hline Konsentrasi $22.5 \mathrm{ml} \mathrm{l}^{-1}\left(\mathrm{~K}_{3}\right)$ & 17.0 & 24.8 & 107.7 \\
\hline Konsentrasi $30 \mathrm{ml} \mathrm{l}^{-1}\left(\mathrm{~K}_{4}\right)$ & 16.8 & 25.3 & 113.8 \\
\hline BNJ 5\% & tn & tn & tn \\
\hline
\end{tabular}

Keterangan: $\quad$ tn = tidak berbeda nyata; *angka yang diikuti huruf yang sama pada kolom yang sama tidak berbeda nyata pada uji BNJ dengan $\alpha=0.05$, MST = minggu setelah tanam.

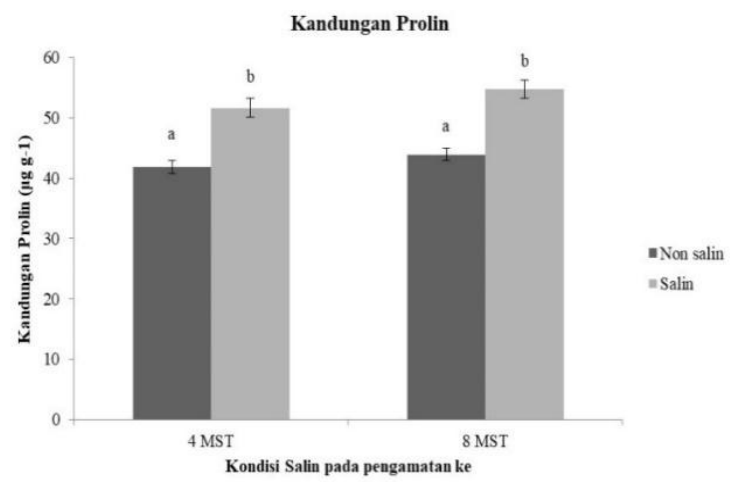

Gambar 1. Kandungan Prolin pada Perlakuan Salinitas

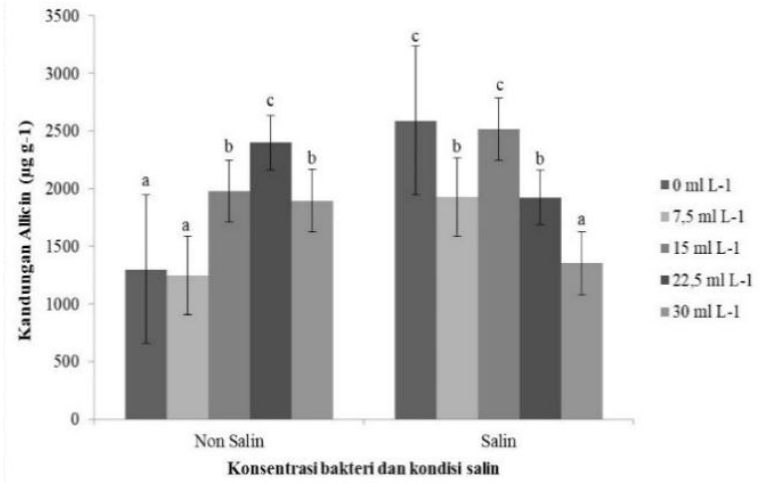

Gambar 2. Kandungan Allisin pada Berbagai Konsentrasi Bakteri 
Peningkatan kandungan prolin tersebut merupakan respon fisiologis bawang merah terhadap cekaman salinitas. Hasil peningkatan konsentrasi prolin akibat cekaman salinitas juga dilaporkan oleh Cha-Um dan Kirdmanee (2009) pada tanaman jagung dan Gharsallah et al. (2016) pada tanaman tomat. Prolin adalah senyawa yang umumnya disintesis oleh tanaman yang mengalami cekamana termasuk cekaman salin. Senyawa ini berperan sebagai osmoregulator yang dapat meningkatkan tugor sel. Konsentrasi prolin meningkat seiring dengan peningkatan salinitas (Sobir et al., 2018). Menurut ElSamad et al. (2010), protein dan asam amino di batang dan akar tanaman jagung dan kacang yang mengandung garam ditandai dengan peningkatan kandungan prolin.

Hasil penelitian menunjukkan bahwa kandungan allisin pada umbi berbeda nyata baik dalam kondisi salin maupun non-salin (Gambar 2). Pada kondisi non-salin, konsentrasi bakteri $22.5 \mathrm{ml} \mathrm{L}^{-1}$ menunjukkan kandungan allisin tertinggi, sedangkan konsentrasi $7.5 \mathrm{ml} \mathrm{L}^{-1}$ dan tanpa bakteri (kontrol) menunjukkan kandungan allisin yang lebih rendah dibanding konsentrasi bakteri yang lebih tinggi. Pada kondisi salin, aplikasi bakteri $15 \mathrm{ml} \mathrm{L}^{-1}$ dan kontrol tanpa bakteri menunjukkan kandungan allisin yang lebih tinggi dibanding perlakuan lainnya. Sebaliknya, penggunaan kosentrasi bakteri tertinggi dalam kondisi non-salin justru menunjukkan penurunan kandungan allisin (Gambar 2). Allisin merupakan hasil metabolism sekunder yang terbentuk oleh enzim allinase yang mampu mengubah alliin menjadi allisin ketika umbi bawang merah terluka (Asili et al., 2010). Kandungan allisin pada umbi bawang merah dalam kondisi salin tanpa isolat bateri ternyata menunjukkan jumlah kandungan yang tinggi dibandingkan perlakuan dengan berbagai konsentrasi bakteri. Hal ini mengindikasikan bawah kandungan allisin meningkat jika tanaman berada dalam kondisi cekaman, seperti salinitas. Aplikasi bakteri dapat menurunkan tingkat cekaman terhadap tanaman namun juga menurunkan kandungan allisin.

\section{KESIMPULAN}

Pertumbuhan dan hasil tanaman bawang merah menurun pada kondisi salin dibandingkan non salin. Peningkatan konsentrasi prolin pada daun merupakan respon fisiologis dari tanaman bawang merah pada kondisi salin. Aplikasi bakteri toleran salin dapat memperbaiki pertumbuhan akar bawang merah dan kandungan klorofil dalam kondisi salin, namun menunrunkan kandungan allisin umbi. Bakteri toleran salin mempunyai potensi dapat dikembangkan untuk meningkatkan pertumbuhan tanaman dan juga perlu diteliti pengaplikasian pada tanaman budidaya lainnya dalam kondisi cekaman salin.

\section{UCAPAN TERIMA KASIH}

Penulis mengucapkan terima kasih kepada Kementerian Riset, Teknologi dan Pendidikan Tinggi Republik Indonesia, yang berkerjasama dengan Lembaga Penelitian dan Pengabdian Masyarakat Universitas Brawijaya yang telah mendanai penelitian ini (338.139/UN10.C10/PN/2018).

\section{DAFTAR PUSTAKA}

Asili, A., J. Behravan, M. R. Naghavi, J. Asili. 2010. Genetic diversity of Persian shallot (Allium ascalonicum) ecotypes based on morphological traits, allicin content and RAPD markers. J. Medic and Aromatic Plants. 1(1):1-6.

Cahyaty, R. A. A., N. Aini, T. Sumarni. 2017. Effect of rhizoshere bacteria bactera application on saline tolerant to proline and chlorophyll contents cucumber. Bioscience Research. 14(4): 949-954.

Cha-Um, S., C. Kirdmanee. 2009. Effect of salt stress on proline accumulation photosynthesic ability and growth characters in two maize cultivar. Pak. J. Bot. 41(1): 87-98. 
El-Samad, H.M.A., M.A.K. Shaddad, N. Barakat. 2010. The role of amino acids in improvement in salt tolerance of crop plants. J. Stress Physiol and Biochem. 6(3): 25-37.

Gharsallah, C., H. Fakhfakh, D. Grubb, F. Gorsane. 2016. Effect of salt stress on ion concentration, proline content, antioxidant enzyme activities and gene expression in tomato cultivars. AoB Plant. 8: 1-19.

Gul, A., F. Kidoglu, Y. Tuzel, I.H. Tuzel. 2008. Effect of nutrition and Bacillus amyloliquefaciens on tomato (Solanum licorpersicum L.) growing in perlite. Span. J. Agriculture Research. 6(3): 422-429.

Jha, Y., R.B. Subramanian. 2013. Paddy plants inoculated with PGPR show better growth physiology and nutrient content under saline conditions. Chilean Journal of Agricultural Research. 73(3): 213219.

Kusumiyati, T.M.O., F.A. Habibah. 2017. Pengaruh konsentrasi larutan garam nacl terhadap pertumbuhan dan kualitas bibit lima kultivar asparagus. J. Horti. 27(1): 79-86.

Motos, J.R.A., M.F. Ortuno, A.B. Vicente, P.D. Vivancos, M.J.S. Blanco, J. A. Hernandez. 2017. Plant responses to salt stress: adaptive mechanisms. Agronomy. 7(18): 1-38.

Nadeem, S.M., Z.A. Zahir, M. Naveed, M. Arshad, S.M. Shahzad. 2006. Variation in growth and ion uptake of maize due to inoculation with plant growth promoting rhizhobacteria under salt stress. Soil and Environm. 25(2): 78-84.
Ohyama, T. 2010. Nitrogen as a Major Essential Element of Plants. In: Ohyama, T. and Sueyoshi, K., Eds., Nitrogen Assimilation in Plants. Research Singpot. Kerala. 1-18.

Radhakrishnan, R., K.H. Baek. 2017. Physiological and biochemical perspectives of non-salt tolerant plants during bacteria interaction against soil salinity. Plant Physiol and Biochem. 116: 116-126.

Rahmi, F., A.D. Susila, E. Sulistyono. 2012. Budidaya bawang merah (Allium ascalonicum L.) pada lahan kering menggunakan irigasi sprinkler pada berbagai volume dan frekuensi. J. Hort. Indonesia. 7(1): 1-8.

Sobir, M., S. Helmi. 2018. Morphological and physiologycal responses of eggplant (Solanum melongena L.) genotypes to salinity stress. J. Hort. Indonesia. 9(2): 131-138.

Taghavi, S., C. Garafola, S. Monchy, L. Newman, A. Hoffman, N. Weyens, T. Barac, J. Vangronsveld, D.V.D. Lelie. 2009. Genome survey and characterizan of endophytic bacteria exhibiting a beneficial effect on growth and development of poplar trees. Applaid and Environm. Microbiol. 75(3): 748757.

Widawati, S. 2015. The role of functional bacteria resistant saline (PGPR) on the growth of rice in sandy soil saline. Indonesia Biodivers. 1: 1856-1860.

Yadav, S., M. Irfan, A. Ahmad, S. Hayat. 2011. Causes of salinity and plant manifestations to salt stress: a review. J. Environ. Biol. 32: 667-685. 